\title{
POVO LAKLÃNÕ/XOKLENG NO/DO VALE DO ITAJAÍ: COSMOLOGIA E MEMÓRIAS E/M RE- EXISTÊNCIAS ${ }^{1}$
}

Pueblo Laklãnõ/Xokleng en/de Valle del Itajaí: cosmología y memorias y/en re-existencias Laklãnõ/Xokleng people in/from the Itajaí Valley: cosmology and memories and/in re-existences

\section{Georgia Carneiro da Fontoura ${ }^{2}$ \\ Lilian Blanck de Oliveira ${ }^{3}$}

\begin{abstract}
Resumo:
A trajetória do Povo Laklãnõ/Xokleng (SC/BR), desde o século XVIII, consiste em contínuos e sistemáticos processos de subalternizações, genocídios e estigmações a definir fronteiras simbólicas e físicas, territórios e territorialidades, que se estendem até os dias atuais, enquanto sombras na construção da memória coletiva regional. Este estudo busca, a partir de "Rodas de Fogo" - Pē Bam Nõdè, socializar dimensões simbólicas e identitárias identificadas nas memórias coletivas do povo Laklãnõ/ Xokleng, que atuam para/na construção de seus territórios e territorialidades, reverberam e articulam processos de resistência e/m luta por seus direitos. Histórias invisibilizadas da narrativa oficial que possibilitam luzes para/na construção de outros olhares e leituras - outros tempos, espaços, lugares regionais.
\end{abstract}

Palavras-chave: Povo Laklãnõ/Xokleng, memória coletiva, cosmologia, resistência, Vale do Itajaí.

\section{Resumen:}

La trayectoria del Pueblo Laklãnõ/Xokleng (SC/BR), desde el siglo XVIII, consiste en continuos y sistemáticos procesos de subordinaciones, genocidios y

1 Este estudo integra a pesquisa de doutorado em Desenvolvimento Regional, de Georgia Carneiro de Fontoura, concluída em 2021, subsidiada por Bolsa CAPES/CNPq. https://bu.furb.br//docs/TE/2021/368065_1_1.pdf

2 Bachiller en Derecho. Maestría y Doctorado en Desarrollo Regional en el PPGDR / FURB. Integrante del Grupo de Investigación Ethos, Alteridad y Desarrollo (GPEAD / FURB). ORCID: https://orcid.org/00000001-8919-0370. Correo electrónico: gecfontoura@gmail.com

3 Pedagoga. Doctora en Teología (EST). Profesora del Programa de Posgrado en Desarrollo Regional (PPGDR / FURB). Líder del Grupo de Investigación Ethos, Alteridad y Desarrollo (GPEAD / FURB). ORCID: https://orcid.org/0000-0002-3755-6630/Correo electrónico: lilianbo29@gmail.com 
estigmatizaciones para definir fronteras simbólicas y físicas, territorios y territorialidades, que se extienden hasta los días actuales, como sombras en la construcción de la memoria colectiva regional. Este estudio busca, desde "Ruedas de Fuego" - Pé Bam Nõde, socializar dimensiones simbólicas e identitarias identificadas en las memorias colectivas del Pueblo Laklãnõ/Xokleng, que actúan para/en la construcción de sus territorios y territorialidades, reverberan y articulan procesos de resistencia y/en lucha por sus derechos. Historias invisibilizadas de la narrativa oficial que posibilitan luces para/en la construcción de otras miradas y lecturas - otros tiempos, espacios, lugares regionales.

Palabras claves: Pueblo Laklãnõ/Xokleng, memoria colectiva, cosmología, resistencia, Vale del Itajaí.

\begin{abstract}
Ever since the 18th Century, the Laklãnõ/Xokleng people have faced continuous and systematic processes of subordination, genocide and stigmatization in pursuing the definition of symbolic and physical boundaries, territories and territorialities as shadows in the construction of the regional collective memory. This study aims at socializing symbolic and identity dimensions that were identified during their "talks around the fire", the Pē Bam Nõde. Such dimensions are part of the collective memories of the Laklãnõ/Xokleng people that work on/for the construction of their territory and territoriality and reverberate and articulate processes of resistance in/for the fight for their rights. History that was made invisible by the official narrative and that may bring light into the construction of new looks and readings - other times, spaces and regional places.
\end{abstract}

Keywords: Laklãnõ/Xokleng people, collective memory, cosmology, resistance, Itajaí Valley.

\section{Palavras iniciais}

O Povo Indígena Laklãnõ/ Xokleng ${ }^{4}$, detentor de uma história e cultura milenares (6 mil anos), originariamente ocupava extensões territoriais no sul do Brasil. Integravam suas áreas de trânsito majoritário, o litoral e planalto catarinense, ao longo do rio Itajaí-Açu. O processo de colonização por imigrantes europeus

4 O Povo Xokleng constituía um dos três grandes grupos indígenas que compunham a formação étnica do Sul do Brasil antes da ocupação europeia. A estes se somam ainda os Kaingang e os Guarani (Santos, 1997). na região sul do país, iniciado no século XVIII, significou um contexto intersocietário, em que o choque e as tensões foram inevitáveis. O indígena antes invisibilizado passa a ser conhecido, culturalmente inferiorizado, expulso de seu território milenar e confinado em outro, para atender os reclames de defesa criados pelo/no imaginário da sociedade regional. O conflito provocado entendido pela sociedade colonizadora como agressão e invasão indígena à população e terras recém ocupadas - significava o oposto, ou seja, 
movimentos de defesa do território e territorialidades tradicionais.

A região do Vale do Itajaí (Santa Catarina, Brasil) se apresenta como o último reduto de fuga e resistência às invasões do território Laklãnõ/ Xokleng, uma migração forçada, “... sem alternativa a não ser 0 enfrentamento direto com os invasores, como forma de garantir seu espaço e um território livre para sua sobrevivência" (Crendô, Jair Ghoguin, 2015, p. 12) . Sr. Cuvei, um dos anciões residentes na atual Terra Indígena Ibirama, ao ser entrevistado por Jair Crendô, assevera: “... nosso lugar não era aqui, fomos empurrados pelo branco, prá ficar nesse buraco, rocha de pedra". (Crendô, Jair Ghoguin, 2015, p. 31, grifo nosso).

O processo de deslocamento do Povo Laklãnõ/Xokleng para o Posto Platê (1914), depois Reserva Duque de Caxias (1926) e atual Terra Indígena (TI) Ibirama (1965) não determinou apenas o espaço físico para esta população, mas designou simbolicamente o "lugar do índio" no Vale do Itajaí. O processo de contato e aldeamento, também lido de forma ampliada como o Tempo antes da Barragem Norte (1914-1972), dentro

5 Devido às citações partirem de narrativas ou trabalhos escritos pelos Laklãnõ / Xokleng, definiu-se por manter seu nome completo nas citações para que seja possível identificar as falas, especialmente devido à presença de pessoas da mesma família (sobrenome). das fronteiras estabelecidas pelo Estado, trouxe consigo mecanismos de/para uma ruptura com seu território milenar e territorialidades (Dagnoni, 2018).

Esta abordagem auxilia na busca de compreensão dos textos e contextos que conduzem, organizam e prospectam o Povo Laklãnõ/Xokleng e sua cosmografia, “... seu regime de propriedade, os vínculos afetivos que mantém com seu território específico, a história da sua ocupação guardada na memória coletiva, o uso social que dá ao território e as formas de defesa dele" (Little, 2002, p.4).

O Tempo do Mato inclui as vivências em liberdade anteriores ao cerceamento territorial, o aldeamento e o contato com o "homem branco"; o Tempo antes da Barragem Norte 6 abarca a perda da liberdade e território milenar provocada pelo governo; o Tempo depois da Barragem Norte compreende a desestruturação territorial, cultural, política e econômica, um andar e/m resistência ao sofrimento. Tudo isso integra a memória coletiva Laklãnõ/Xokleng, pois "o passar do tempo não apaga

6 A construção da Barragem Norte ao lado da Terra indígena Ibirama, na década de 70, com o objetivo de conter históricas cheias que assolam o Vale do Itajaí, decretou ao Povo Laklãnõ/ Xokleng a perda de seus territórios férteis e consequentes processos de desintegração cultural e organizacional. 
o conhecimento dos movimentos do grupo, desde que se mantenha viva a memória dos ancestrais" (Ramos, 1986, p. 19-20).

Elemento constituinte do modo de ser indígena, a roda de fogo, é lugar em que as narrativas através das memórias (ancestralidade) se tornam práticas e realidade no presente. "Nas aldeias, as rodas de conversas nos ajudam a contar e reconstruir nossa história que erroneamente foi contada" (Pripra, Walderes Cocta, 2021, p.27). Segundo Xumayá Xya, indígena Fulni-ô em diálogo com Raquel Cintra, jornalista:

A fogueira são os homens, as mulheres, as crianças e os anciões. Somos toda a base de um só elemento que transmite uma força para toda a aldeia. Os índios mais velhos têm mais conhecimento, mas precisam dos índios mais novos para realizar as coisas. Somos todos, a nosso modo, uma força só. ... A madeira são os homens, que dão estrutura à aldeia. As mulheres são o fogo, que se unem a eles. Já as cinzas Thinia, são anciões, que não precisam fazer nada, mas têm a função vital de manter a chama acesa. Ah, e essa fumaça, que incomoda seus olhos...é ela que leva todos os pensamentos dos que fazem parte dessa roda para o grande espírito. (Xumayá Xya, 2020)
O espaço da Roda de Fogo é carregado de simbologias que trazem consigo a importância do encontro, da reunião, do corpo comunitário. É também lugar do ser-saber-fazer cultural através do acolhimento e transmissão da tradição, da conversa, da escuta, do repartir, do conjugar, do (re)construir. Como dizem os anciões e os professores, o modo Laklãnõ/ Xokleng de aprender é aprender na/ com prática, ou seja, caminhando junto, comendo junto e, ao redor do fogo, ouvindo com atenção as palavras daqueles que já caminharam e viveram muitas experiências.

As Rodas de Conversa ou Rodas de Fogo reúnem elementos promotores da oralidade, em que as histórias contadas fazem a narrativa - relatam, transmitem conhecimentos, sentimentos e lembranças $\mathrm{e} / \mathrm{m}$ experiências vividas - sementes de rememoração em um terreno coletivo. De acordo com Maurice Halbwachs (1990, p.26) "em realidade, nunca estamos sós", existem tantas memórias quantos grupos, comunidades e/ou povos existirem.

A história oral é de suma importância para a comunidade, pois envolve a vida cotidiana de cada um; quando o indivíduo memoriza uma narrativa, ele tem a sua própria experiência com ela, para poder assim transmiti-la em determinado momento, ao redor do 
fogo, em acampamentos de caça ou em momentos nos quais ele via a necessidade de repassar esses conhecimentos para relembrar acontecimentos passados. (Pripra, Walderes Cocta, 2021, p.15)

A cultura de cada povo indígena existe de forma articulada, onde seus múltiplos elementos, sistemas de valores e significados estão interrelacionados e nada existe que não esteja em relação com o todo do qual é parte integrante. Sua cosmopercepção ${ }^{7}$ impregna seu cotidiano e viceversa, a experiência mais imediata e espontânea de sua realidade é concebida como sagrada: o nascimento, a morte, os acontecimentos diários e extraordinários da vida da pessoa ou da história da comunidade, a natureza em suas dádivas e ensinamentos, o universo que habitam e os habita (Markus e Oliveira, 2005).

7 O termo cosmopercepção é um conceito cunhado pela epistemóloga nigeriana de origem iorubá, Oyèrónkẹ́ Oyěwùmí. A cosmopercepção “é uma maneira mais inclusiva de descrever a concepção de mundo por diferentes grupos culturais (...) que podem privilegiar sentidos que não sejam o visual ou, até mesmo uma combinação de sentidos" (Oyěwùmí, 2002, p. 393). A utilização deste termo não nega a noção da cosmovisão, mas a amplia e traça uma crítica ao horizonte eurocentrista no qual a visão é valorizada em detrimento a outros sentidos. Esta perspectiva envolve dimensões da percepção humana que ultrapassam as fronteiras da visão - do "ver". A experiência da existência ultrapassa o que é visto, pois é tecida por muitos outros sentidos. (Oyěwùmí, 2017).
Nestesentido, buscamosinspiração na simbologia e materialidade da Roda de Fogo - uma Pée Bam Nõde $\bar{e}^{8}$ para socializar e trazer, a partir das falas de anciões, anciãs, homens e mulheres do povo indígena Laklãnõ/Xokleng, dimensões simbólicas e identitárias que consubstanciam a memória coletiva de seu povo, e que atuam para/na construção de seus territórios e territorialidades na atualidade, reverberando e articulando processos de resistência e/m luta na insurgência por seus direitos.

\section{Pē Bam Nõdē Cultura: "jeito de ser Laklãnõ/Xokleng” - um andar em memória e resistência}

A cultura de um povo é resultado das territorialidades construídas pelos sujeitos que habitam um dado território - uma dimensão que visibiliza sua identidade, seu ser e estar no mundo. No caso dos Laklãnõ/Xokleng, para Walderes Cocta Pripra (2021, p.15), as memórias do povo são "o que distingue a nossa forma de viver, aprender, de se organizar na simplicidade e de se expressar é também o que dá sentido a todo esse conhecimento cultural. Isso torna rica a cultura".

O "jeito de ser Laklãnõ", no próprio dizer do povo, é o modo de ser que configura a identidade

$8 P \bar{e}$ Bam Nõdē na terminologia da língua Laklãno/ Xokleng significa: Roda de Fogo. 
Laklãnõ/Xokleng - sua cosmologia e cosmopercepção envolve sua espiritualidade, as manifestações culturais, a forma como se organizam enquanto sociedade e grupo cultural. Os Laklãnõ/Xokleng apresentam um termo que o exprime: o "andado do indio" - o seu caminhar na existência. Nas palavras de Carli Caxias Popó9, é um caminho/ar que, apesar de ter muita dor, sofrimentos, desafios, "conseguiram seguir cultivando a cultura Laklãnõ a seu modo, tempo, espaço e possibilidades" (Popó, Carli Caxias, 2015, p.33) - um caminhar de (re)existências e/m esperanças.

A força da resistência Laklãnõ/ Xokleng está contida em suas raízes, no elo que sustenta sua existência no hoje - sua caminhada ancestral que estrutura sua cultura e resplandece em sua identidade. "Hoje buscamos na memória dos anciãos algo que possa nos dar força para lutar por nossos direitos e viver essa nova história" (Patté, Allair Ngaumm, 2015, p.22).

Para os Laklãnõ, a sabedoria que vem desde seus ancestrais é muito importante, porque descreve também a própria cultura, na medida em que possibilita a capacidade de conhecimento, habilidade de um

9 “... pelos caminhos onde o meu povo andou, há tanta dor, tantos desafios, mas conseguiram seguir cultivando a cultura Laklãnõ a seu modo, tempo, espaço e possibilidades". (Popó, Carli Caxias, 2015, p.33) determinado povo. Ela é construída de forma conjunta e reúne todas as experiências do povo através dos tempos. Quando surge um desafio, obviamente que esta sabedoria será como uma ferramenta, um instrumento capaz de fazer com que a pessoa ou o grupo consulte o passado para dar uma resposta ao problema atual. (Popó, Carli Caxias, 2015, p. 21).

Assim, o que já foi e o que virá não estão separados temporalmente, nem espacialmente - existem em um só tempo e espaço no espírito Laklãnõ/ Xokleng, consagrado em sua memória coletiva. Nas palavras de Oliveira, é a "trama e urdidura da existência" de seu povo, que consubstanciam a ontologia e existência de cada indivíduo.

Entrelaçando-se os fios do tempo e do espaço cria-se o tecido do mundo que articula a trama e a urdidura da existência. A ancestralidade é um tempo difuso e um espaço diluído. Evanescente, contêm dobras, labirintos e desdobram no seu interior e os corredores se abrem para o grande vão da memória. A memória é precisamente os fios que compõem a estampa da existência. (Oliveira, 2007, p. 245).

Trata-se de uma estampa onde tons e movimentos em um tracejado, de forma perceptível e/ou imperceptível, remete aos seus ancestrais e, ao mesmo tempo, lhes reconstrói e dá continuidade aqui e agora-um sistema, 
na linguagem Laklãnõ/Xokleng. "Assim, o sistema não é agora, vem de lá do passado. Não é agora" (Sr. Ivo, Memórias Laklãnõ/Xokleng, 2018). O "sistema do índio" é seu modo de ser, sua organização social. São "sistemas organizados de símbolos significantes que orientam a existência humana". (Geertz, 1989, p.58).

Segundo o antropólogo Silvio Coelho dos Santos (1997, p. 119), "sua tradição é contrária às diversas formas de acumulação. $\mathrm{O}$ coletivo ainda predomina sobre o individual". Sr. Ivo, ancião Laklãnõ/Xokleng, registra que "quando vive no mato a vida assim ainda é. Eles come junto cos filho, junto cos neto, o índio, né? Esse é sistema do índio. O que eles têm reparte pro filho, reparte pros neto. Assim é." (Sr. Ivo, Memórias Laklãnõ/ Xokleng, 2018). Se alguém tem demais, divide, faz uma festa ou gasta com presentes. Assim, os Xokleng continuam sendo mantenedores dos espaços da diferença cultural, que lhes permite continuar a ser índio, a ser um povo". A isso Arturo Escobar (2015) denomina de "territórios de diferença".

... é por isso que quando ele vai tirar da natureza, ele só tira o que é essencial, o que ele necessita, e é só pra aquele momento, ele não faz estoque, porque o sistema laklãnõ xokleng ele não tem visão capitalista. O capitalismo para ele não tem valor, ele não consegue se manter porque é dessa forma que o povo Xokleng ele se organiza, né. Muitas vezes a gente não é entendido por pensar dessa forma, você olha às vezes as pessoas e diz assim: o povo Xokleng quer muita terra sabendo que é dentro do espaço que eu preciso tirar meu medicamento, o meu alimento, né...nós somos responsáveis pela natureza e a natureza é responsável por nós, a gente faz essa reciprocidade com a natureza, é dessa forma que a gente vai sobrevivendo (Osias Tucugm Paté, Conversa com Povo Laklãnõ sobre Território Tradicional, 2020, grifos nossos).

A reciprocidade com a natureza mencionada por Osias rompe com a divisão binária natureza/sociedade, e busca nas relações milenares dos sistemas integrais de vida e conhecimento dos povos ancestrais dar outros sentidos à colonialidade da natureza e da própria vida. Segundo Maldonado, "la reciprocidad es una práctica de prestigiamiento social, de abundancia económica, de legitimidad política y de fortaleza espiritual. A través de ella se redistribuyen los excedentes y se logra un equilibrio social y económico". (Maldonado, 2014, p. 200).

A práxis da reciprocidade sustenta a organização comunitária dos povos indígenas, de modo que "a cada acto humano o divino se debe corresponder, como finalidad integral, con un 
acto recíproco y complementario equivalente entre sujetos. Dar para recibir es una obligación social y ética" (Maldonado, 2014, p. 204). Esta visão do sistema Laklãnõ/Xokleng questiona $\mathrm{o}$ padrão produtivista e consumista de organização do planeta, já que seus modos de ver e viver persistem resistentes às lógicas moderno-coloniais que engendram as perspectivas de desenvolvimento de nossos tempos. Essa é uma perspectiva que coaduna com o Bem Viver:

... O Bem Viver com sua proposta de harmonia com a Natureza, reciprocidade, relacionalidade, complementariedade entre indivíduos e comunidades, com sua oposição ao conceito de acumulação perpétua, com seu regresso a valores de uso, o Bem Viver, uma ideia em construção, livre de preconceitos, abre as portas para a formulação de visões alternativas de vida. (Acosta, 2016, p. 33).

O sistema Laklãnõ/Xokleng se organiza em um caráter ontológicoterritorial, partindo de uma ontologia onde a natureza possui espíritos - o rio, as montanhas, as árvores são seres que possuem espíritos, constituem vínculos $\mathrm{e} / \mathrm{m}$ territorialidades simbólicas e espirituais. Escobar nos ajuda a entendê-lo:

...densa red de interrelaciones y materialidad a la que llamamos "relacionalidad" u "ontología relacional... Para resumir, una ontología relacional puede definirse como aquella en que nada (ni los humanos ni los no-humanos) preexiste las relaciones que lo constituye. Todos existimos porque existe todo. (Escobar, 2015, p.93).

Trata-se de um sistema que se contrapõe à perspectiva dualista moderno-colonial, que separa o humano e o não humano, a natureza e a cultura, nós e os outros - prismas de uma ontologia dualista (Escobar, 2015).

Os velhos acreditam que as árvores são também guardiãs de memórias, carregam consigo a ligação dos tempos material e imaterial e carregam consigo as andanças dos indígenas. Oferecem o alimento e a cura para/do corpo, alma. Ao passarem por uma árvore, os velhos relembram e contam histórias, acontecimentos que compartilharam com ela e vice-versa no decorrer da vida" (Cuzugni, Vilma Couvi Patte, 2020, p. 15)

A ontologia - elemento profundo de sua espiritualidade - parte da compreensão de que as realidades humanas e sociais estão interligadas à relação com a natureza. Sua espiritualidade envolve o reconhecimento das realidades humanas e sociais em profunda conexão com a natureza. Os elementos 
que estão em seu território são entidades materiais e espirituais.

Desde sempre o povo Xokleng/ Laklãnõ tem a natureza como mãe e por isso o respeito por ela. Acreditamos que ela também dá seus sinais quando algo acontecerá, há uma espiritualidade que só os Laklãnõ conseguem descrever em suas conversas e contam que as árvores conversam com nós humanos, é preciso aprender e saber ouvi-las. (Cuzugni, Vilma Couvi Patte, 2020, p. 31)

Os Laklãnõ/Xokleng estabelecem diálogo com a natureza, seus animais sagrados, plantas, movimentos - em um profundo elo com a vida - "Para este povo não existe separação entre homem e natureza, mas uma interação, no diálogo com os pássaros, nas orações dirigidas aos ancestrais. A natureza e o sobrenatural também podem se comunicar com as pessoas, trovões, pássaros entre outros, que entendemos como uma cadeia de vida." (Popó, Carli Caxias, 2015, p.12).

A natureza é compreendida como mãe, aquela que provê, que cuida, que alimenta e sustenta a vida: "Mãe Natureza porque muitas vezes ela cuidou de nossos ancestrais, livrandoos eles muitas vezes de serem mortos; também porque dela que vêm nossas crenças, nossos mitos e histórias. Estão totalmente ligados à natureza" (Criri, Voia, 2020, p. 12).

... Segundo o relato da Elaine K. Camlém: "ela chegou a conhecer seu bisavô que veio da mata. Segundo ela, ele contava várias histórias do nosso povo e em um dos relatos que ela se recorda é que certa vez o povo Xokleng em um de seus conflitos com os zug (povo branco), o líder do grupo de luta pediu aos que estavam atrás dele para se esconderem atrás das árvores. Fizeram conforme o mandado de seu líder, seus corpos se transformavam em árvores e os que estavam perseguindo eles passavam das árvores e não viam eles, por isso que os povos indígenas chamam atualmente de Mãe Natureza". (Criri, Voia, 2020, p.12).

Segundo a percepção espiritual do povo Laklãnõ/Xokleng, existem diferentes universos: o superior e o inferior, o céu e a terra.

Sob este olhar e no entender do povo, na parte superior há seres sobrenaturais semelhantes a seres humanos, mas com vidas imortais. Já na parte inferior que é a terra, ficou claro também que há seres humanos, mas com vidas mortais. Neste aspecto de diferente universo, os Laklãnõ/Xokleng diferenciavam no passado que há céu na parte superior e que lá há vida, e na parte inferior que é terra, também há 
vidas que são humanos. (Weitschá, Micael Vaipon, 2015, p. 31).

Kamblém $^{10}$, líder espiritual do povo, conhecido como kujá, "no início dos anos 30 em suas últimas palavras antes de falecer, apontou para o céu no sentido oeste e disse que a porta do céu (buraco) ficava ali naquela direção e que estaria subindo com um Ser com o nome 'Ju, Juju' e ficaria junto dele e se precisar de alguma coisa é só pedir e ele estaria intercedendo por eles". (Weitschá, Micael Vaipon, 2015, p. $31)$.

Para o povo Laklãnõ/Xokleng, o cosmos está constituído por várias forças espirituais. Segundo sua crença ancestral, cada ser da natureza possui um espírito ao qual denominam kuplê, que deve ser respeitado. Não existe somente uma co-existência, mas uma relação e/m diálogo.

Para o povo Lakãnõ/Xokleng a espiritualidade vem dos "gajúg" (ser sobrenatural, espírito do mal e bem) e do "kuplénh" (fantasmas ou almas), pois acreditavam que esses espíritos se manifestam de várias formas, como se fossem animais, árvores ou outro ser da natureza. $\mathrm{O}$ "kuja" conhece todos os espíritos

10 Encontramos diferentes grafias para este e outros nomes na língua Laklãnõ/Xokleng, em que escolhemos a que fosse possível de ser redigida com os recursos que temos, sem, contudo, desconsiderar a diversidade da grafia encontrada, própria de um povo de tradição oral. conhecidos como "kluplénh" e é quem pode fazer o contato com eles. (Criri, Voia, 2020, p.10)

No laudo antropológico, descrevese que "muitos Xokleng lembram que, ao passarem por ali, seus pais e avós apontavam e falavam a respeito da existência de tal referência significativa à reprodução física e cultural indígena". (Pereira et al., 1998, p. 21). São marcadores territoriais - marcos territoriais que utilizam para descrever sua história, e que estão gravados na memória - consagração de lugares como referenciais - marcos territoriais Lakãnõ/Xokleng.

Conforme o tempo de caça e coleta estavam em um determinado lugar, assim se reencontravam para fazer seus rituais, como casamentos, purificação das viúvas, perfuração do lábio inferior dos meninos, tatuagem de identificação na perna esquerda das meninas, ou ainda para fazer as trocas de novos conhecimentos com outros grupos do mesmo povo. Existiam pontos de referência para povo se localizar, desta forma dominavam um extenso território (Tschucambang, Copacãm, 2015, p. 10).

Para Adnilson de Almeida Silva, a concepção de marcadores territoriais "pode ser compreendida a partir dos símbolos que ocorrem enquanto espaço de ação, definem territorialidades vinculadas à cosmogonia e experiências 
socioespaciais e possibilitam a formação das identidades culturais e do pertencimento identitário" (Silva, 2010, p.105).

De tal modo que passa a ser possível compreender o espaço por meio das representações simbólicas e sígnicas, pois estes marcadores territoriais “... são experiências, vivências, sentidos, sentimentos, percepções, espiritualidade, significados, formas, representações simbólicas e presentificações que permitem a qualificação do espaço e do território como dimensão das relações do espaço de ação". (Silva, 2010, p.105).

A forte ligação com a terra indica como o alimento, o afeto e a identidade estão emaranhados num complexo tecido social. São laços indissociáveis, que fortalecem o povo e o lugar. Os hábitos alimentares são compostos por uma rede de significados e possuem uma relação simbólico-cultural de intrínseca ligação com o território tradicional.

O comportamento/habitus ${ }^{11}$ alimentar engloba aspectos biológicos,

11 Para Bordieu, habitus pode ser compreendido como “... um sistema de disposições duráveis e transponíveis que, integrando todas as experiências passadas, funciona a cada momento como uma matriz de percepções, de apreciações e de ações - e torna possível a realização de tarefas infinitamente diferenciadas, graças às cognitivos, situacionais e afetivos com significados individuais e coletivos. É um instrumento de identificação social interligado com os sistemas de relações sociais e de significados. "O item cultural 'alimentos' torna-se parte inseparável de um sistema articulado das relações sociais e de significados coletivamente partilhados" (Gonçalves, 2007, p. 163).

Silva (2013) compreende a comida (alimento) enquanto um componente afetivo, que recorda e organiza as relações e a identidade individual e coletiva do grupo. A memória por meio da alimentação evoca rituais familiares e comunitários ativados pelo paladar ou olfato. Assim, a prática alimentar tradicional tem o poder de convocar o passado - conectando com nossas memórias. "... Alimentarse es uma conducta que se desarrolla más allá de su propio fin, que sustituye, resume o señala otras conductas; $y$, en esa misma medida, la alimentación constituye un signo". (Contreras, 1992, p. 102). De acordo com João Cricri:

Antes do contato dos Laklãnõ (Xokleng) com os não índios, a caça era farta. A mata era virgem e nela existiam inúmeras espécies de animais silvestres como: porco do mato, veado, anta, cateto, e outros animais que eram caçados. Quando o caçador chegava com a caça,

transferências analógicas de esquemas ...” (Bourdieu, 1983, p. 65). 
outras pessoas do grupo dividiam o animal em pedaços com as pessoas presentes e o caçador ficava só com o que sobrava como a cabeça e a buchada. A caça era feita com arco e flecha, lança e armadilhas como o mondéu. Agora com o passar dos tempos a realidade é outra. Os poucos animais silvestres que temos estão em extinção e muitos já desapareceram de nossas matas. A coleta que era mais praticada, era a coleta do pinhão nos meses de maio a agosto. (Criri, João, 2015, p.14).

A comida está ligada ao modus vivendi do ser humano, envolve as dimensões social, cultural, econômica e política da alimentação, como também as representações simbólicas decorrentes da rede de relações sociais que identificam o alimento a uma determinada sociedade ou a algum segmento dela. Assim, o alimento se constitui em um produto cultural, pois é por meio do alimento e da alimentação que o homem se revela e revela seu grupo social.

Mesmo com a drástica mudança na vida e nos hábitos alimentares da sociedade Laklanõ/Xokleng e, embora seus conhecimentos com a natureza "tenham sofrido considerável perda após o contato com a sociedade não indígena, o uso de recursos naturais está ainda presente como parte da cultura e da memória coletiva dessa sociedade" (Gakran, 2015, p. 34).
A culinária, devido à redução das terras e o desmatamento dela, teve que ao longo do processo de pacificação se adaptar ao do não indígena, pouco se tem ainda da culinária tradicional, ela continua viva na memória dos velhos, que relembram com nostalgia do que tempo que colhiam frutas na mata, pesca nos rios, entre tantos outros ingredientes da culinária tradicional. Embora todo processo de contato com a cultura não indígena, os velhos da T.I. ainda preservam o conhecimento sobre a medicina tradicional, porém, assim como na culinária, as folhas e raízes são encontradas no pouco de mata que ainda resta e, devido ao processo de desmatamento, como eles argumentam, está se torando cada vez mais difícil a prática da medicina. (Tschucambang, Josiane de Lima, 2020, p. 16-17).

Dentre os saberes e práticas alimentares Laklãnõ/Xokleng, o preparo do alimento é feito no fogo por meio de tecnologias tradicionais, assim como denomina João Criri (2015) em sua pesquisa sobre a alimentação tradicional Laklãnõ (Xokleng). É na fogueira que se prepara pag de klágnē ou kagklo (carne de caça ou peixe cozido em folha de caeté) e o totol (farofa de farinha de milho) e o kapug (bolo de milho na taquara). Acir Kaile, entrevistado por Voia Criri, assim se refere sobre esse tema: 
Hoje vejo que parte da população mais jovem do meu povo não conhece essas crenças devidas algumas interferências bruscas após o contato. Vão citar aqui um desses agravantes que é a construção da barragem norte que dividiu o povo e acelerando a perda cultura do nosso povo acabando a com os grupos familiares a troca de afeto e novas descobertas e troca de experiências em reuniões familiares não bastando tudo isso só, mas também parte dos costumes alimentares cita um dos alimentos principais o peixe a caça na beira do rio que sumiu com as grandes enchentes, o peixe já escasso, não existe mais fartura como era antes da barragem, varia espécies de peixes não existe mais e caso do peixe conhecido pelo povo de vugvug que o povo sempre gostou de saborear. (Criri, Voia, 2020, p. 15)

O conjunto de tudo isso em todos os grupos é sempre de natureza espiritual, são propriedades sagradas entrelaçadas de memórias, que compõem ritos e (com)vivências. (Bosi, 2003). Os artefatos tradicionais são elementos simbólicos que remontam o modo de ser tradicional e carregam consigo a memória de experiências vividas, de temporalidades afetivas. São objetos que dão um "assentimento à nossa posição no mundo, à nossa identidade; e os [objetos] que estiveram sempre conosco falam à nossa alma em sua língua natal" (Bosi, 2003, p. 26). "Os artefatos Xokleng carregam história que se fundamenta na cultura do povo." (Tschucambang, Copacãm, 2015, p.9).

Em sua pesquisa, os anciões identificam e recordam os artefatos arqueológicos apresentados, os nomes nativos, histórias e significados associados, para que serviam e em que ocasiões eram utilizados no passado. "No passado antes do tal da pacificação estes instrumentos eram indispensáveis, pois eram usados no pilão para moer os seus alimentos no dia a dia. Eles eram era tão importantes que eram passados de geração em geração." (Tschucambang, Copacãm, 2015, p.43).

Como apontam os anciões e anciãs, assim como os professores e professoras, a transmissão de geração a geração dos saberes do povo -o modo Laklãnõ-Xokleng de aprender- é na prática, ou seja, caminhando junto, comendo junto e, ao redor do fogo, ouvindo com atenção as palavras daqueles que já caminharam e viveram muitas experiências, aprendendo através da memória coletiva, “... ouvindo eles contando".

... a educação indígena é assim. Eles ensinam em volta do fogo, é o que eles faziam. Em volta do fogo eles fizeram tudo isso enquanto as crianças estavam brincando igual nós tinha as crianças aqui. Então eles faziam a ideia, depois as crianças sentavam no meio e ouviam tudo 
aquilo lá. [...]a educação indígena ela é bem interessante, ela não é... igual eu falei de nós ir lá no quadro, fica escrevendo, tentando fazer o aluno aprender, ele não é assim. As crianças não vieram aqui porque eles tão em aula, senão eles ficam tudo aqui em volta e eles aprendem, aprendem dessa forma. Então nós aprendemos, nós acostumamos assim, então nós aprendemos assim ouvindo eles contando. (Miriam Priprá, Memórias Laklãnõ/ Xokleng: Saberes e Resistências da e na Aldeia Bugio 2018).

A construção de sistemas próprios de educação, desenvolvidos com e por suas comunidades, possibilitam a formação do espaço-tempo para o uso e valorização da língua materna e de fortalecimento identitário. Este lócus tende a motivar os estudantes indígenas à escuta dos "mais velhos", ao envolvimento com sua história, ao acesso a memórias coletivas que formam o seu modo tradicional de ser e de dizer/ler o mundo.

Os anciões da comunidade estão assistindo as aulas e ajudando as crianças a compreender essa nova época que estão vivendo. Porém, em suas falas, a natureza, a mata é a grande escola, a natureza é o elemento fundamental para a vida do povo. Representa a vida, força e renovo para o dia a dia. (Cuzugni, Vilma Couvi Patte, 2020, p. 40).
A escola, hoje, para além do que compreendemos como escolarização, é o lócus de pertencimento identitário e "tem sido o principal meio para resgatar muitos aspectos culturais que estavam adormecidos". (Pripra, Walderes Cocta, 2021, p.15). Dessa forma, a história do povo ganha vida e é contada para as crianças muitas vezes através da sua língua materna que "fortaleceu-se e revitalizou-se em nosso âmbito escolar como mecanismo de enfrentamento e resistência à sociedade envolvente". (Paté, Abraão Kovi, 2014, p.95). A escola passou a ser instrumento: "a escola que, no passado, muito contribuiu para a perda da cultura, hoje vem sendo um veículo de propagação e fortalecimento dos conhecimentos" (Tschucambang, Copacãm; Tschucambang, Josiane de Lima, 2018, p.24).

Neste espaço-lugar se reúnem os signos de toda uma história de luta e sobrevivência, onde resistem por entre linguagens e saberes próprios, (pró)vitalizando quem são por meio de aprendizagens interculturais. Tais aprendizagens se disseminam na educação trazendo outras percepções - exercícios alteritários. Trata-se de uma educação que reflete o exercício e a práxis de onde se quer ir, quem se é, trazendo uma totalidade e corporeidade de percepção do ser e estar no mundo. 
3. Pē Bam Nõdē território "mãe terra": lugar no espaço/tempo Laklãnõ/Xokleng

O território é esteio da vida, lócus que possibilita a existência humana em suas múltiplas dimensões (Haesbaert, 2004). Do laço com ele, comungamos no decorrer da vida e encontramos o elo de pertencimento ao chão - terreno, material e simbólico. (Bonnemaison, 1996).

A dimensão territorial abrange, acolhe e dá possibilidades ao serestar-fazer humano, ou seja, o tempoespaço-lugar para vir a ser cultura dimensão ontológica de um dado grupo e/ou povo. No caso do povo Laklãnõ/ Xokleng, a terra é mãe que nutre, acolhe e dá sustento à vida - uma relação sagrada, pois sua concepção de mundo e de viver é interligada umbilicalmente ao solo da terra, a qual mantém ligação cosmológica indissociável, de modo que sua corporeidade é a da terra.

Bonnemaison compreende que "a correspondência entre o homem e os lugares, entre uma sociedade e sua paisagem, está carregada de afetividade e exprime uma relação cultural no sentido amplo da palavra". (Bonnemaison, 2002, p. 91). À luz desta concepção, Airton Krenak trata da relação de pertencimento com base na perspectiva indígena. "Pertencer a um lugar é fazer parte dele, é ser a extensão da paisagem, do rio, da montanha. É ter seus elementos de cultura, história e tradição nesse lugar. Ou seja, em vez de você imprimir um sentido ao lugar, o lugar imprime um sentido à sua existência". ${ }^{12}$

O território carrega consigo os significados culturais e simbólicos a ele atribuídos - são lugares sagrados transpiram atributos da territorialidade de um povo com o espaço. Esta compreensão nos auxilia a entender a percepção do território à luz do povo Laklãnõ/Xokleng, enquanto lugar em que estão entretecidas sua identidade, espiritualidade, compreensão de mundo - sua existência. Refere-se ao "nosso jeito de viver depende da nossa terra" - espaço e lugar para existir, um lugar para continuar vivendo como Laklãnõ/Xokleng.

$\mathrm{Na}$ visão Laklãnõ Xokleng, território não fica pra mim unicamente em 14 mil hectares e 37 mil hectares. Território é o espaço sagrado pra mim onde eu encontro a minha medicina, a minha alimentação, eu acho que é esse espaço que eu chamo de território, que o povo Xokleng chama e muitas vezes isso não é entendido por que a terra para os Xokleng. Prá mim como Xokleng é a mãe, se a mãe adoecer não tem como ela cuidar de um filho, né... e pra nós ela é sagrada, a mata é sagrada, o animal ele é respeitado. (Osias Tucugm

12 https://www.goethe.de/ins/br/pt/kul/fok/ ags/21806968.html 
Paté, Conversa com Povo Laklãnõ sobre Território Tradicional, 2020).

Para Baniwa (2016), o “[...] território enquanto espaço de vida, onde vivem na integralidade, tem a ver com o passado, o presente e o futuro. Essa relação sagrada, essa relação espiritual, orgânica com a natureza, tem uma força muito grande e que não pode ser quebrada". Assim, o território indígena $^{13}$ envolve uma relação ontológica e espiritual - "Ali é onde viviam nossos avós/antepassados" que elabora um profundo "respeito à terra, não só como chão sagrado que alimenta e dá vida, mas também como morada dos espíritos" (Povo Deni e Sass, 2014, p.35).

13 Uso da expressão "território" pelos indígenas, como tradução à língua colonial (no caso, o espanhol) das múltiplas concepções por eles utilizadas. Isso demonstra o quanto esse "giro territorial" entre as comunidades indígenas -ou, mais amplamente, dos povos tradicionais- pode/deve ser percebido como uma via de mão dupla: das categorias específicas dos povos originários à designação "território" e desta, em seu uso normativo/ hegemônico e/ou analítico, em direção e em ressignificação pelos grupos autóctones. Sempre considerando também, é claro, a multiplicidade dessa concepção entre os próprios povos originários. $\mathrm{O}$ conceito de território se transforma $\mathrm{em}$ uma "espécie de noção-fetiche e um conceito em disputa, tanto para as organizações indígeno-camponesas quanto para outros movimentos urbanos ou rurais ... que alcançou o território não apenas como uma categoria da prática, vinculada a seu uso no senso comum, mas também como categoria normativa, no âmbito das políticas oficiais do Estado". (Haesbaert, 2021, p. 136).
Nas palavras do Sr. Aniel Priprá, ancião Laklãnõ/Xokleng que faleceu recentemente, "A nossa terra é nossa mãe." (Conversa com Povo Laklãnõ sobre Território Tradicional, 2020). O território Laklãnõ/Xokleng representa para o grupo não só a apropriação de um território marcado pelas relações de poder, como estratégia política e social, mas também o lugar para manutenção da memória herdada pelos ancestrais e repassada aos descendentes, que se materializam nas relações de vizinhança, solidariedades costumeiras, e contribuem na construção das suas territorialidades e identidades - lugar da identidade étnica ou da territorialidade étnica, como "expressão de um comportamento vivido" (Bonnemaison, 2002, p. 107).

A ideia de etnia e de grupo cultural interessa ao geógrafo porque traduz a ideia de um espaço-território. De fato, a territorialidade emana de etnia, no sentido de que ela é, antes de tudo, a relação culturalmente vivida de um grupo humano e uma trama de lugares hierarquizados e interdependentes, cujo traçado no solo constitui um sistema espacial - dito de outra forma, um território (Bonnemaison, 2002, p. 96-97).

Oterritórioélugar ${ }^{14}$ no qualo grupo nutre uma relação afetivo-identitária,

14 Para Tuan (1983) "Lugar é uma porção do espaço onde está desenvolvido um pequeno mundo: esta porção é dotada de significados, valores e ritmos por aqueles que a experienciam”. Esta concepção 
portanto é lugar onde a memória reforça os vínculos afetivos $\mathrm{e}$ identitários daquela coletividade com aquela porção do espaço, "por meio da evocação de representações de tempoespaço que alimentem esse sentimento de pertencimento recíproco entre o grupo e o território". (Tuan, 1983).

Este território-lugar, na perspectiva de Tuan (1983), possui diferentes escalas espaço-temporais que podem ser experimentadas nas paisagens, no imaginário, nos rituais, nas memórias, de forma coletiva ou individual. Neste sentido "memória e territorialidade passam a se influenciar mutuamente, já que o próprio território passa a ser, além de elemento identitário de grande relevância, também um importante vetor dessa memória coletiva, repleto de signos que atuam nesse sentido." (Neto, 2021, p.21).

As territorialidades demarcam o vínculo do Povo Laklãnõ/Xokleng com o território tradicional, pois este "não provém do simples fato de viver num lugar, mas da comunhão que com ele mantemos" (Santos, 1997, p. 62). Para Baniwa (2016), "[...] como o lugar é sagrado, este espaço territorial é sagrado. Há uma relação espiritual das pessoas, das famílias, dos povos indígenas com este território". Nas palavras do povo Laklãnõ/Xokleng

de lugar dá "elementos para pensar o território oriundo da vivência cotidiana do espaço." "é uma terra que pertence a nós, hoje tem cemitério dentro destas terras, cemitério indígena, tem o corpo do nosso pajé" (Aniel Pripra, Conversa com Povo Laklãnõ sobre Território Tradicional, 2020).

Na região da Serra da Abelha, munícipio de Vitor Meireles, encontra-se um cemitério Xokleng onde está enterrado o pajé Kamlém. O local conhecido como Kaklei-kle, era um paradouro do grupo, onde se encontravam e faziam a festa de casamento, segundo o ancião Veitchá Téie (Pereira et al., 1998).

Kamlém, segundo a memória do povo, estava acampado com um grupo nesta região, quando ficou doente e acabou falecendo no local. Antes de morrer deixou uma ordem ao grupo para que não fosse cremado e que o enterrassem ali, pois previa que os não-índios iriam invadir, tomar aquelas terras, assim, seu corpo serviria como prova de que a terra pertencia ao povo.

A cultura é a soma dos comportamentos, dos saberes, das técnicas, dos conhecimentos e dos valores acumulados pelos indivíduos durante suas vidas e, em uma outra escala, pelo conjunto dos grupos de que fazem parte. A cultura é herança transmitida de uma geração a outra. Ela tem suas raízes num passado longínquo, que mergulha no território onde seus 
mortos são enterrados e onde seus deuses se manifestaram (Claval, 2002, p.63).

Pela apropriação territorial, o povo tem seus territórios identitários, sentindo-se pertencente ao lugar e tecendo em e com ele suas territorialidades, suas memórias e sua cultura. Por isso a desterritorialização significa "a separação entre o grupo e aquela porção do espaço, a 'perda' do território, ... ea consequente 'destruição' destes signos (ou ao menos a perda de contato para com eles) costuma ter impactos tão fortes sobre a memória coletiva e, consequentemente, sobre os processos identitários do grupo social" (Neto, 2021, p. 21). Nesta perspectiva, indicam Brighenti e Osmarina:

A luta não é apenas pela posse das terras, a disputa dá-se sobre memórias coletivas em que o tempo é totalmente distinto para as partes envolvidas. Enquanto que para os não-indígenas a referência temporal 50 ou 100 anos é um argumento forte para exigir pertencimento e memória. Para os indígenas, é uma pequena parcela de um outro tempo, não linear, nem balizado pelas justificativas metodológicas das leis e justiça brasileira, mas incide sobre práticas, saberes e memórias milenares transmitidas na oralidade. (Brighenti e Osmarina, 2014, p.24).
É por meio da oralidade e das narrativas dos mais velhos que o povo Laklãnõ/Xokleng retorna/revisita seu território tradicional, caminha através dos tempos, relembra o jeito de ser Laklãnõ. Os anciões e anciãs perpetuam a transmissão da matriz simbólica do grupo - um elo de permanência em movimento de tempos e lugares. Carregam consigo a memória ancestral de todo um povo - "os anciões da TI Ibirama Laklãnõ, por entender que estes são o repositório da história do Povo Laklãnõ/Xokleng" (Patté, Allair Ngaumm, 2015, p.16).

Para os Laklãnõ/Xokleng, os mais velhos detêm um lugar sagrado no seio do seu povo. São reconhecidos como guardiões da sabedoria - sua sabedoria vem dos ancestrais, os "mais velhos", anciãos e anciãs, detentores da sabedoria adquirida pela vivência, "ela é construída de forma conjunta e reúne todas as experiências do povo através dos tempos" (Popó, Carli Caxias, 2015, p.21).

Conforme Quintero Weir, “... toda territorialização de qualquer lugar do mundo, por parte de qualquer comunidade humana, não só expressa o tempo da comunidade humana que o executa, como tal processo de territorialização estará sempre carregado do tempo do mundo em si mesmo". (Weir, 2019, p.17) 
Assim, as produções materiais e simbólicas esculpidas no tempo se comunicam como presente e participam das produções do território (Flávio, 2011) e da identidade cultural de um grupo - sua relação de pertencimento - e se constituem "vínculos espirituais e simbólicos que dão sentido à vida e valores ao território" (Haesbaert, 2004, p. 21). Estas experiências e vivências estão consubstanciadas na memória coletiva que, como nos lembra Halbwachs (1990), se desenvolve num quadro espacial.

As memórias guardam as relações, interações e dinâmicas socioespaciais que se transformaram no e pelo tempo, revestidas de sentidos afetivos, sociais e simbólicos, representando um modo de percepção do espaço vivido - sistema de territorialidades que se entrecruzam.

Essa noção de território indígena recupera o sentido simbólico e cosmológico de espaço tradicional e ancestral, uma vez que, com a tradição de relembrar os tempos dos antigos, os povos indígenas nunca ficam sem o território de onde emergiram na origem do mundo e onde estão presentes nos rituais, nas crenças, nas histórias e mitos. (Baniwa, 2015, p. 128)

Segundo Raffestin (2009, p. 31), "na produção territorial sempre tem um ponto de partida que nunca é ileso das ações do passado. O processo territorial desenvolve-se no tempo, partindo sempre de uma forma precedente, de outro estado de natureza ou de outro tipo de território."

Para Little (1994), a memória coletiva é uma das formas mais importantes dos povos para localização no espaço geográfico. $\mathrm{O}$ ato de rememoração conecta os temposlugares da sua história, realiza uma viagem através da cartografia da memória da existência e traça "a pluralidade de possibilidades de significações e relações com o espaço vivido, impossibilitando uma concepção de território como categoria genérica e exterior aos sujeitos que nele habitam". ${ }^{15}$ A professora Laklãnõ/Xokleng Miriam Priprá, no documentário "Memórias Laklãnõ/ Xokleng: Saberes e Resistências da e na Aldeia Bugio" (2018), descreve esta experiência, ao relembrar momentos em que o Sr. Paulo, ancião já falecido, esteve junto aos estudantes e professores contando histórias de seu povo.

... o falecido Paulo, quando ele vinha conversar com nós aqui na escola, ele falava isso prás crianças: eu talvez não vou existir mais, mas eu tô passando essa história pros professores, eles vão passar

15 Adriana Werneck Regina. O espaço vivido pelos Panará: o sentido vivido no espaço. https://files. cercomp.ufg.br/weby/up/306/o/ComunAdrianaWerneke.pdf 
pra vocês da maneira que eu tô contando, vocês vão lembrar um dia que eu cheguei aqui na escola e contei isso pra vocês. Quando alguém contar a história vocês vão lembrar, o Paulo falou assim, assim. Vocês vão junta e vão faze uma história. Ele falava. E ali quando ele fez as cabanas com nós professores, junto com os alunos, ele ficou o tempo todo contando história, então foi uma apresentação livre que foi feito junto com o Paulo. As crianças tudo como nós tamos aqui, os professores tudo vestido, a Kundi lembra, né Kundin. Ele fez junto com os professores, dois barracos ali, típico mesmo, nós sentamos em volta do fogo no chão como era e ele ficou contando a história prás crianças. Ele disse assim, enquanto eu vou contando a história, as mães vão servindo as crianças e as mães sentam também. Umas vão servindo outras sentam como fosse normal. E parece que foi uma realidade. Porque eu sentei com as crianças no chão e a Kundir ficou servindo nós. Então parece... hoje eu lembro, foi uma história muito... até o pessoal que tava fora assistindo se emocionaram, parecia uma realidade, com comidas típicas mesmo. Então isso traz força prá nós. É isso que traz força pra nós, que eles foram mas eles deixaram um legado pra nós e quando nós lembramos daquela fala, ele dá uma resistência. (Miriam Priprá, Memórias Laklãnõ/Xokleng: Saberes e Resistências da e na Aldeia Bugio, 2018, grifo nosso).
Esta fala exprime a experiência da conexão por meio da narrativa de um ancião com outros tempos-espaços da existência do grupo. Não é a existência de uma corporeidade estranha ou externa, mas que possui profundas relações de pertencimento com quem comunga do mesmo espírito - ser Laklãnõ/Xokleng. De tal modo que a experiência "parecia uma realidade", vivenciada no tempo presente, trazendo a existência de outros tempos-lugares vividos.

Deste modo, o território atua como suporte identitário, e as narrativas e seus desdobramentos repercutem na representação territorial. "As narrativas indígenas estão imbricadas de espiritualidade e contribuem no estabelecimento das relações territoriais e do modo de se representar como coletivo e de se presentificar com os demais coletivos". (Silva, 2013, p.113).

O território indígena se opõe à visão "antropocêntrica, racional e instrumental" do território ${ }^{16}$. A racionalidade do território é uma imposição de caráter ocidental,

16 A compreensão e denominação jurídica dos territórios indígenas "transformou o território em "um dos termos-chave dessa nova linguagem étnico-política" (Echeverrí, 2004, p. 259), distinto, contudo, do uso jurídico-político (espaço de soberania, notadamente estatal) e das ciências naturais (espaço de reprodução e fonte de recursos para a sobrevivência)" (Haesbaert, 2021, p. 135) 
concepção que fragmenta o indivíduo, o limita e determina. Historicamente, a intervenção no território é realizada por órgãos do Estado com planos que, aparentemente, fornecem soluções para situações sociais. "En este marco, lo que 'ocupa' es el proyecto moderno de Un Mundo que busca convertir a los muchos mundos existentes en uno solo; lo que persevera es la afirmación de una multiplicidad de mundos" (Escobar, 2015, p. 99).

A perseverança das comunidades e movimentos étnico-territoriais envolvem resistência, oposição, defesa e afirmação, mas muitas vezes podem ser descritos mais radicalmente como ontológicos, como defesa da vida no exercício da autonomia, o direito à paz, à liberdade e à vida nos territórios coletivos. São movimentos que não buscam somente um território para viver, mas apontam outra ótica, a dimensão da vida - uma dimensão ontológica e ética. (Escobar, 2015).

\section{Adefesa de seus direitos territoriais} é uma luta ontológica: "las luchas por los territorios se convierten en luchas por la defensa de los muchos mundos que habitan el planeta" (Escobar, 2015, p. 93). Envolve um projeto de vida comunitária, na defesa do território como espaço que sustenta seus projetos de vida, baseado em práticas e valores de sua visão de mundo, a partir de uma perspectiva étnico-territorial.
O Povo Xokleng, pensando numa forma de não deixar a floresta morrer, em atos ritualísticos, vem dando o nome de árvores em vias de extinção a seus filhos acredita-se que dessa forma ela nunca morrerá. ... Essas atitudes, reafirmam para nós indígenas que uma planta medicinal, uma árvore nativa, frutífera ou não, têm uma história e uma utilidade para o Xokleng/Laklãnõ, e isso não pode ser esquecido e muito menos ignorado. ... E, quando os mais jovens resolvem nomear seus filhos com nomes de plantas ou outros significados com total certeza na vida de cada criança renasce uma história Laklãnõ, revive uma planta que já estava extinta. Renasce com o nome, entes queridos na vida das famílias e para o povo. (Cuzugni, Vilma Couvi Patte, 2020, p.8; p.30; p.40) ${ }^{17}$.

17 "Na crença Xokleng/Laklãnõ a criança ao receber o nome da árvore se tornará responsável por ela, o ancião ao dar o nome para criança conta a história da árvore, o significado e utilidade dela para os Xokleng/Laklãnõ, a criança então tem como meta cuidar para que a árvore não morra e se ela não existe mais, é instigado a criança quando crescer, trazer de volta a árvore para aldeia" (Cuzugni, Vilma Couvi Patte, 2020, p.13).

"Meu companheiro sugeriu que déssemos um nome que tivesse a ver com nossa cultura, mas que não fosse ligado a nome de pessoas. Precisava ser um nome que chamasse atenção para algo importante na nossa cultura e assim ele fez uma lista de nomes, mas quando ela nasceu percebemos que ela tinha bastante cabelos, o que chamou atenção de quem chegava para visitar. Alguns dizem que parecia com samambaia, de onde originou seu nome. Nossa filha se chama Plinã (samambaia esticada ou estendida). Os velhos Xokleng/Laklãnõ contam que, nos tempos antigos, nas andanças, quando ainda existia mata, eles usavam os ramos 
Atualmente, diante dos recursos normativos e procedimentais disponíveis, o laudo pericial antropológico pode trazer elementos que aclaram a compreensão das territorialidades tradicionais. Entretanto, um laudo antropológico ou uma peça judicial não conseguem abarcar a complexidade de modos de vida. Estes ainda se subscrevem enquanto elementos que auxiliam a percepção do Estado acerca dos sujeitos, povos, culturas e histórias, trazendo outros parâmetros aos cânones jurídicos que ultrapassam as compreensões e lógicas individualistas e patrimonialistas em que foram construídas nossa sociedade.

Neste sentido, pensar em direito à propriedade compreende uma postura do Estado que reafirma uma perspectiva civil-patrimonialista de garantia do direito de propriedade, entendida como um direito absoluto, que desconsidera o caráter coletivo dos sujeitos coletivos. Os laudos e perícias antropológicos enquanto

da samambaia para fazer suas camas, onde pernoitavam. Plinã veio a nós pela natureza e representa o lugar onde é possível descansar, representa também reflexão e sabedoria, pois é também quando deitamos nosso corpo em repouso que podemos viajar pelos olhos da imaginação, pelo que vimos, vivemos e olhamos assim para o futuro. Representa parte dos modos de vida do Povo Xokleng/ Laklãnõ e ao receber o nome, ela se torna também parte e guardiã dos costumes antigos, das memórias que suscitam seu nome". (Cuzugni, Vilma Couvi Patte, 2020, p.26). procedimentos administrativos $\mathrm{e}$ judiciais, têmpossibilitadouma “...nova reconfiguração de saberes, propiciada por um campo de pesquisa que conjuga o envolvimento das comunidades pesquisadas, dos pesquisadores de várias áreas, militantes de movimentos sociais, dos profissionais de entidades e instituições públicas, entre outros" (Chagas, 2005, p. 71).

O laudo antropológico reconstruiu mais de 80 anos de lembranças transmitidas oralmente entre as gerações deste povo. É o registro da memória desta gente que se opõe judicialmente à versão das escrituras formais do histórico de destinação daquelas terras. A ligação dos povos indígenas com o território tem relação com sua espiritualidade e mito de criação - são lugares de origem que demarcam no espaço suas origens - "É o lugar onde o umbigo foi enterrado. Outra forma de relação com o território é por meio dos significados culturais e simbólicos atribuídos a estes - são lugares sagrados - transpiram atributos da territorialidade de um povo com o espaço. Essas terras, das quais foram expulsos em tempos passados, são prenhes de memórias e de tradição, é o lugar onde o 'umbigo foi enterrado', são sagradas e por isso devem ser devolvidas." (Brighenti e Oliveira, 2014, p. 37). 
Os Laklãnõ/Xokleng - são povos de/em movimento e nem por isso sem território - as relações interétnicas do processo anterior à colonização estabeleceram os territórios destes povos, que constantemente passavam por confrontos entre os grupos. Este povo tem consciência de que suas bases territoriais extrapolam os limites do território da TI Ibirama.

O lugar onde foram encontrados [artefatos] são lugares que o povo vivia antes da chamada "pacificação", mas mesmo pós-contato o povo continua frequentando o lugar que antes fazia parte de seu território tradicional. A resistência dos Laklãnõ/Xokleng para manter a alta mobilidade dentro do seu território foi enfraquecendo devido à ocupação de não indígenas no território tradicional, o que ocorreu antes e pós-contato, pois eles sabiam a época certa de explorar a região, fazendo uma forma de rodízio dos locais percorridos. (Tschucambang, Copacãm, 2015, p.50).

"Cada povo deslocado procura, de uma ou outra forma, sua relocalização no espaço. $\mathrm{O}$ processo de criar um espaço novo torna-se, assim, primordial, e se dá, em parte, pela manipulação múltipla e complexa da memória coletiva no processo de ajustamento ao novo local". (Little, 1994, p. 11)
Os Laklãnõ/Xokleng, mesmo restritos e "limitados" ao território da Terra Indígena nestes mais de 107 anos, nunca deixaram de andar em seus caminhos tradicionais. Sua relocalização no espaço não é em um território desconhecido, seu território tradicional é reduzido pela investida do processo colonizador, e a atual Terra Indígena Laklãnõ passa a ser seu último reduto de fuga. Neste espaçolugar ocorre sua re-territorialização movimentos de re-organização social e cultural para "adaptação" a um fragmento de seu território - uma outra territorialidade no espaço.

Asegunda RodadeFogo-dimensão de território que os identifica e articula com um passado memorial- os fortalece e confere identidade imemorial que organiza suas territorialidades no sentido comunitário, assim como além dele, reverberando e articulando de forma ontológica-cultural suas lutas em resistência cotidianas e seculares. O caminhar Laklãnõ é um marco deste povo, que mesmo com as investidas de políticas estatais para sua sedentarização, nunca deixou de "fazer seu caminho" - a mobilidade é sua marca e identidade, persiste e vive na memória de um povo que segue caminhando abaixo do Sol. 


\section{Pē Bam Nõdē Memória: 'Ãg Jug Óg Jógzẽ Txi, f̃g Zẽ Txi' 18 - sementes de rememoração Laklãno/Xokleng}

Para os povos indígenas, a ancestralidade carrega consigo a memória de seu grupo, conecta os tempos-espaços-lugares - uma cartografia da existência - que entretecem e dão força à sua reexistência no hoje. No caso do povo Laklãnõ/Xokleng, a ancestralidade é acessada através dos anciões eanciãsque "consideram muito importante relatar esses conhecimentos, emocionamse ao narrar as histórias antigas, ... os anciãos têm plena consciência de sua importância no atual movimento de revitalização dos saberes nativos e evidenciam prazer e compromisso em transmitir estes conhecimentos, buscando a sua preservação para as próximas gerações" (Pripra, Acir Caile, 2020, p.9)

Este elo com o passado vivido exige que sementes de rememoração (Halbwachs, 1990) encontrem um terreno sólido no grupo de referência e de pertencimento para que as lembranças sejam reconhecidas e reconstituídas.

Não basta reconstituir pedaço por pedaço a imagem de um

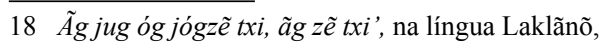
significa 'as histórias dos nossos antepassados'. acontecimento passado para obter uma lembrança. É preciso que esta reconstituição funcione a partir de dados ou de noções comuns que estejam em nosso espírito e também no dos outros, porque elas estão sempre passando destes para aqueles e vice-versa, o que será possível se somente tiverem feito e continuarem fazendo parte de uma mesma sociedade, de um mesmo grupo. (Halbwachs 1990, p. 39).

Munduruku (2010) compreende os velhos como as memórias de um povo, que transmitem histórias, conhecimentos, experiências de seu povo, a fim de que suas culturas continuem e perpetuem para as próximas gerações. Para os Laklãnõ/ Xokleng os velhos “... são a base para o contato com o passado, mas também uma ponte para pensar o futuro". (Tschucambang, Josiane de Lima, 2020, p. 7).

Os relatos dos anciões e anciãs são experiências que dão "formas para reviver o que está adormecido" (Criri, Voia, 2020, p. 13). Não são lembranças alheias a sua existência, mas memórias coletivas que têm lugar na vida do grupo, dão e são sentido à existência no aqui agora. Desta forma, partimos para a compreensão de que os saberes passados dos mais velhos para os mais novos representam formas próprias de resistência ou de mudança, levando em consideração 
que as palavras trazem múltiplas manifestações. (Meliá, 1979).

Nas sociedades indígenas, os mais velhos são responsáveis pela transmissão dos elementos culturais, desde a cosmologia, os ritos, os costumes e suas histórias. Suas narrativas recriam mundos, tempos e experiências do mundo vivido pelo grupo. Os anciões e anciãs são uma marca do passado no presente, um elo atemporal que conecta gerações ao espírito do grupo.

Daniel Munduruku (2017, p. 42) retrata que "foi assim que aprendi a vida de meu povo: ouvindo histórias". Os anciãos são os "guardiões da memória" e os detentores do "poder de aconselhar" - toda a narrativa é um aconselhamento. (Benjamin et al., 1983). O aconselhamento trás força, é saber que, através da palavra, sopra e dá sentido à existência, conecta os tempos, espaços e lugares. Nas palavras de Jozileia Kaingang (2021) ${ }^{19}$, o saber é como uma brasa que está adormecida e precisa de um assopro no momento certo para que possa reacender uma chama e espalhar para todos os parentes que precisam dela. "As falas dos velhos se remetem a um passado em que participaram, viveram as emoções que, muitas vezes, são de tristeza e poucas

19 Licenciaturas Interculturais: trançando memórias e compartilhando saberes https://www.youtube.com/watch? $\mathrm{v}=\mathrm{dE} 6 \mathrm{e} 5 \mathrm{fMIH} 4$ de alegria. As narrativas se deram em forma de aconselho para quem ouve." (Tschucambang, Josiane de Lima, 2020, p. 32).

De acordo com Carli Caxias Popo (2015, p. 21). “[...] nossos ancestrais conseguiram preservar a cultura Laklãnõ e isso fez com que não esquecessem a sua identidade cultural". Esta frase traz consigo a grandiosidade com que os Laklãnõ/ Xokleng têm e transmitem a sua ancestralidade - "traz força pra nós" (Miriam Priprá, Memórias Laklãnõ/ Xokleng: Saberes e Resistências da e na Aldeia Bugio 2018). A existência deste povo é construída a partir da resistência dos anciões e anciãs viventes, que simbolizam a consciência da ancestralidade e dão sustento à história, às existências e/m re-existências. “... Eles passam pra nós e aquilo vai dando força, vai criando força com aquilo que o mais velho, o pai, o avô passou pra gente." (Miriam Priprá, Memórias Laklãnõ/Xokleng: Saberes e Resistências da e na Aldeia Bugio 2018).

A língua é fonte de registro histórico, acessa as raízes ancestrais, o vivido, o experienciado e o transcendente. Ao ser pronunciada, o idioma materno reelabora imagens do passado, é condutor entre o imanente e o transcendente - reverbera através dos tempos - espaços imateriais/ 
imaginários onde se projetam suas esperanças - têm vida e força de existência.

De acordo com Osias T. Patté (2015, p. 15) “[...] nós Laklãnõ/ Xokleng buscamos preservar a cultura do nosso povo, principalmente a língua, que consideramos o principal elemento de identificação Laklãnõ/ Xokleng". A língua é o traço de quem somos, nos representa, conta histórias, transmite conhecimentos e nos revela. É o código utilizado para traduzir e expressar nossos pensamentos e sentimentos.

... mesmo que estejamos apresentando a importância, existência e valorização de uma cultura local, existe séries de situações críticas em relação à manutenção e uso da Língua Laklãnõ, uma vez que os falantes são poucos, precisamente só os mais velhos é que falam, enquanto seus filhos, a nova geração, só compreendem a Língua Laklãnõ, assim como tem outros que já não compreendem mais. Essa preocupação é justamente por causa da necessidade de manter viva a memória da história do povo Laklãnõ, isto é, sem o conhecimento e domínio de uma língua não é possível conhecer uma história. (Popó, Carli Caxias, 2015, p. 17).
Assim, a preocupação com a preservação da língua materna Laklãnõ "não é simplesmente para que as pessoas falem ou se comuniquem na sua língua específica, mas que continuem a possibilidade de conhecer sua cultura a partir de suas linguagens". (Popó, Carli Caxias, 2015, p. 17).

$\mathrm{O}$ ensino do idioma materno vem sendo incorporado nas escolas indígenas da TI Ibirama. "A revitalização da língua Laklãnõ/ Xokleng tem sido uma das grandes tônicas a desafiar e amalgamar os processos de reconhecimento e fortalecimento da memória, vida e cultura do povo na direção de uma efetiva participação social" (Bento, 2018, p. 40). Para Abraão Kovi Patté (2014, p. 97), é “uma forma de revitalizar o que não puderam aprender e que não lhes foi ensinado ${ }^{20 "}$.

Iniciei a $1^{\text {a }}$ série do ensino fundamental pela primeira vez no

20 Há registros de que Lino Nunc-foon-ro, ex-aluno do professor Mieczyslaw, e posteriormente professor contratado pela FUNAI para dar aulas na Escola Federal Getúlio Vargas, na então reserva Duque de Caxias, trabalhava na língua materna Xokleng com os estudantes, sempre com medo de ser descoberto. "Isso se configurou como um princípio de resistência. Ele ensinava e explicava, mais na oralidade, poucas vezes escrevia, pelo fato de a pronúncia na língua materna dar o significado do que era impossível de forma escrita na língua portuguesa. Dessa forma a língua portuguesa se transformou num código com sentidos diversos. Entendo que ele é um dos pioneiros da revitalização da língua materna Xokleng" (Paté, Abraão Kovi, 2014, p. 97). 
ano de 1989 , tendo aulas com uma professora não indígena. Éramos em cinco colegas na minha turma, três eram meus primos e os outros dois eram crianças da comunidade, ou seja, da mesma aldeia que a minha. ... Lembro-me de que não entendia nada do que a professora falava, apenas adivinhava ou imitava os meus colegas, pois eles já falavam a língua portuguesa. Afinal, na minha casa só se falava a língua materna do meu povo. (Criri Neto, Aristides Faustino, 2015, p. 20)

O Sr. Renato Kovi Kamlém, 53 anos, em conversa com Padilha, indica o seguinte:

... talvez seja um erro nosso, nessa parte de ensinar a língua materna, pela evolução constante ao nosso redor. Falo pouco com os meus filhos no idioma, porque quando eu era criança não sabia falar o português e tive muita dificuldade na escola. Quando aprendi, era novidade para mim, por isso falava só português, e acabei ensinando os meus filhos também. Hoje, eu vejo que fiz muito mal em não ter ensinado os meus filhos no idioma. Esse erro trouxe muitas consequências, como ficarmos desinformados das nossas histórias, cerimônias, cânticos, e tudo que envolve a nossa cultura. (Padilha, Margarete Vaicome Patte, 2020, p. 15, grifo nosso)

A língua é repositória do acervo cultural de um povo, de onde se depreende a "... necessidade de manter viva a memória da história do povo Laklãnõ, isto é, sem o conhecimento e domínio de uma língua não é possível conhecer uma história" (Popó, Carli Caxias, 2015, p.17). As palavras que a compõem possuem significações únicas, ligadas à identidade sociocultural daquele povo. De acordo com Graciela Chamorro, a palavra "é o símbolo que contém, exibe, recria, visualiza e comunica uma outra realidade diferente dele, mas ao mesmo tempo presente nele". (Chamorro, 2008, p.278). É sua forma de expressão e comunicação - de ler e interpretar o mundo - "cada língua contém sua própria maneira de conceber o homem e a natureza, de sentir alegria e tristeza, e de encontrar um significado para os acontecimentos." (Sachs, 2000, p. 355).

A linguagem é constituída de símbolos coletivos, que são construídos e lapidados histórica e culturalmente, e permitem ao ser humano avançar do "aqui e agora" para espaços e tempos diferentes. "Cada língua humana é um sistema único de comunicação e expressão das experiências históricoculturais e cosmológico-simbólicas da comunidade que a fala e, portanto, o legado mais autêntico da ecologia de uma sociedade humana". (Chamorro e Martins, 2015, p.743).

A criança Xokleng/Laklãnõ em cada família é nomeada em memória de um parente que se foi: "acredito 
que parte da minha bisavó está em mim." (Patté, Ana Roberta Uglõ, 2015, p.9) O sistema de nominação é um "meio de não esquecer os nomes dos velhos", e torna manifesta a identificação do grupo. É comum que as crianças recebam nomes de parentes já falecidos, ingressando no mundo social. Através do nome e das pinturas de seu grupo, é possível a identificação e posição social no povo, refletindo um mecanismo de organização social. Os registros mencionam também que as pinturas "serviam para afastar os espíritos (Kuple.ng)", possuindo um forte símbolo espiritual da cosmologia do povo. (Santos, 1997).

Dei o nome de meu pai avô para que meu filho herdasse os conhecimentos e sabedoria dele, era assim que antigamente os nomes também eram dados às crianças. Era dado um nome do mato ou de algum animal, nome de um parente ou ancestral, ao receber o nome entendia que a criança carregaria consigo todo ensinamento e história, saber contido nele. Um nome não era dado porque era bonito, mas também pela significância contida nele. (Cuzugni, Vilma Couvi Patte, 2020, p. 24).

A linguagem e os rituais, assim como o mito, acessam o tempolugar onde os sentidos da memória encontram-se vivos, atualizando o passado e ajudando a modificar e compreender o presente. Eles revivem outros tempos e lugares, (re) criando um espaço vital através do qual a ancestralidade fala e é ouvida. "Praticar os ritos trás força e o sentido à existência" (Kluge, Anderson Rodrigo, 2020, p.24), uma vez que detém a capacidade de fazer reviver "... o espaço e os referenciais míticos em um outro espaço com outros referenciais. $\mathrm{O}$ mito traz consigo seu lugar vivencial... Não é o seu significado que é aprendido a partir de seu lugar vivencial. O mito se refaz, através do rito, em um novo lugar vivencial. É assim que se ancora a fé". (Whestelle, 1990, p. 261).

Uma história considerada pela academia, "os intelectuais", como "mito", mas o povo Laklãnõ/ Xokleng acredita que em algum momento da vida quer seja no passado recente, no passado distante ou remoto, mas foi vivida pelos seus ancestrais, que atualmente é vivenciada como: 'ãg jug óg jógzẽ txi, ãg zẽ txi', ou seja, 'as histórias dos nossos antepassados', as histórias dos ancestrais', por isso, ainda é respeitada como maior tesouro desta sociedade. (Weitschá, Micael Vaipon, 2015, p. 18).

Segundo Popó, a cosmologia na visão Laklânõ/Xokleng parte da compreensão de que os mitos não somente revelam a história, mas são eles que fazem a história - entendendo a história como a realidade que quebra a noção de tempo, passado e presente. $\mathrm{O}$ mito não procura apenas uma 
explicação, mas cria realidades. (Popó, Carli Caxias, 2015).

A conexão entre a cultura Laklãnõ e seus respectivos rituais é outro modo de lidar com a memória tradicional. Em certo momento, os rituais descrevem a própria história, a história de ações de demiurgos. Além disso, expressam acontecimentos do passado que passaram a se estabelecer como fontes de crenças, tradições. No caso dos Laklãnõ se estabelece a apresentação da cosmovisão de sua cultura que tem seus fundamentos tradicionais com base nas histórias vivenciadas pelos seus ancestrais, mas que tem uma conectividade contínuo para o contexto sociológico, ou seja, o reflexo de um contexto mítico para o contexto sociológico é muito presente entre os Laklãnõ, incluindo o nascimento, crescimento, bem como a própria morte. (Popó, Carli Caxias, 2015, p. 11).

As raízes da vida comunitária estão fortemente ligadas à espiritualidade do povo, suas práticas sagradas, suas territorialidades $\mathrm{e} / \mathrm{m}$ relações com o espaço vivido. Assim, a cultura e, nela, a espiritualidade, permitem manter laços de unidade enquanto unem os membros das comunidades em torno a uma luta pela defesa de seus próprios direitos "En este sentido la espiritualidad indígena es, desde lo cultural, una espiritualidad de resistencia y reivindicación política" (Calvo, 2017, p.187).

Os povos indígenas têm em sua memória coletiva e em sua história o registro de saberes medicinais de cura. A biodiversidade do ambiente em que estavam sempre foi acionada para o uso em chás, emplastros, compressas, puxamentos, massagens e práticas de benzimentos e xamanismo. E, até o contato com os não indígenas, a medicina tradicional bastava para tratar e curar as enfermidades dos indígenas Laklãnõ Xokleng (Camlém, Elaine Kosiclã, 2020, p.22)

Para os povos indígenas, sentir a terra é conectar-se com as vivências ancestrais. É sentir e perceber a permanência na impermanência do tempo e do ser - acessar e se re-viver as/nas memórias. Os anciões e anciãs são sementes de rememoração que reconfiguram sua existência ancestral nos atuais territórios físicos, sociais e culturais - dimensão da ancestralidade que, através de temporalidades $\mathrm{e} / \mathrm{m}$ existências, têm sua reverberação e articulação na construção de territórios físicos e simbólicos, trazendo força e resistência à luta por seus direitos por entre as gerações.

\section{Palavras não finais: iluminando novas rodas $\mathbf{e} / \mathrm{m}$ vivências}

É possível identificar um extenso e minucioso trabalho nas escolas 
e comunidade educadora da Terra Indígena Ibirama nos últimos anos, no tocante a busca, registro e (pró) revitalização de aspectos históricos e culturais Laklãnõ/Xokleng. A partir de pesquisas, diferentes eventos e rituais ancestrais deste povo, os aspectos históricos e culturais têm sido rememorados e reconstruídos como forma de um fortalecimento identitário - compreensão de sua identidade e reconfiguração de seu lugar na sociedade regional.

Os movimentos internos desta etnia e sua população têm reverberado no contexto regional e para além deste, em virtude das relações e tessituras que decorrem dos projetos e respectivos processos em desenvolvimento. Alguns desses projetos são: realização e/ou participação em eventos e projetos nas universidades e escolas da região; interação com a sociedade envolvente por meio da abertura de trilhas para visitação na Terra Indígena Ibirama, e atividades na Semana dos Povos Indígenas (abril) e Contato (setembro); construção e/ou acessibilidade a políticas afirmativas de acesso ao ensino superior; participação ativa em organismos civis e públicos; entre outros.

Tais atividades constituem-se em formas de luta e resistência no/do território de seus antepassados - reexistir em tempos de esperança a um lugar de viver e/m possibilidades ${ }^{21}$, dignas de um Bem Viver. Rememorar detém o poder de identificar um fio que une o passado ao presente, fortalecendo e identificando a jornada comum - uma tessitura em lembranças e resistências materializada em signos e significados ancestrais, que consubstanciam o presente e forjam o futuro.

Tempos, lugares, territórios, territorialidades e cosmovisão Laklãnõ/ Xokleng são (re)vividas através da memória coletiva e transmitidas pelas/ nas narrativas dos anciões e anciãs, nos ritos e mitos, nas rodas de conversa, lócus em que experiências de vida, interrelações com o mundo, saberes e conhecimentos milenares projetam uma realidade simbólica - um viver em outros tempos eoutras territorialidades ainda existentes - significando força que conduz sua luta e resistência, o modo de ser Laklãnõ Xokleng na atualidade. Uma caminhada Laklãno/ Xokleng embaixo do sol em busca de outros tempos melhores e ainda possíveis, Tempos de Esperança.

21 Para Boaventura Santos "possibilidade é o movimento do mundo" (Santos, 2004, p. 796). 


\section{Referências}

Acosta, Alberto. (2016). O bem viver. Uma oportunidade para imaginar outros mundos. Autonomia Literária, Elefante.

Baniwa, Gersem. (2006). O Índio Brasileiro: o que você precisa saber sobre os povos indigenas no Brasil de hoje. Ministério da Educação, Secretaria de Educação Continuada, Alfabetização e Diversidade; LACED/ Museu Nacional.

Baniwa, Gersem. (2015). Autonomia indígena no Brasil: desafios e possibilidades. Em: Duprat, Débora (Org). Convenção n. 169 da OIT e os Estados Nacionais. ESMPU, p.117-137.

Baniwa, Gersem. (2016). O Território Indígena. Entrevista para Projetos "Povos Originários de Nuestra América" e "Indígena Digital" do IELA. https://www.youtube.com/ watch? $\mathrm{v}=$ svrUf6f1w5E

Benjamin, Walter et al. (1983). Textos escolhidos. $2^{\circ}$ ed. Abril Cultural.

Bento, Karla Lúcia. (2018). Povo Laklãnõ/Xokleng e/em processos de decolonização: leituras a partir da Escola Indígena de Educação Básica Vanhecu Patté - Aldeia Bugio. (Tese de doutorado em Desenvolvimento Regional. Programa de Pós-Graduação em Desenvolvimento Regional, Universidade Regional de
Blumenau). https://bu.furb.br// docs/TE/2018/364848_1_1.pdf

Bonnemaison, Joel. (1980). Espace géographique et identité culturelle en Vanuatu (exNouvellesHébrides). Journal de la Société des océanistes, 181-188.

Bonnemaison, Joel. Cambrezy. (1996). La Lien entre frontierès et identités. Géographie et Cultures, n.20, 6-15.

Bonnemaison, Joel. (2002). Viagem em torno do território. Em: Correa, Roberto L.; Rosendahl, Zeny. Geografia cultural: um século (3). Eduerj, p. 83-132.

Bosi, Ecléa. (2003). O tempo vivo da memória: ensaios de psicologia social. Ateliê Editorial.

Bourdie, Pierre. (1983). Sociologia. Ática.

Brighenti, Clovis Antonio; Oliveira, Osmarina de. (2014). Espaço, memória e territorialidade: as terras indígenas em SC. Cadernos do CEOM, v. 20, n. 27, 21-42

Calvo, Carlos Alberto Osorio. (2017). Religiosidad e identidade: la lucha indígena como resistencia territorial desde la Espiritualidad. Kavilando, v. 9, n.1, 184-203.

Camlém, Elaine Kosiclã. (2020). Cândida Patté, parteira tradicional do Povo Xokleng Laklãnõ: retomada de práticas tradicionais e a saúde das mulheres. (Tese de Licenciatura Intercultural 
Indígena do Sul da Mata Atlântica, Centro de Filosofia e Ciências Humanas, Departamento de História, Universidade Federal de Santa Catarina). https://repositorio.ufsc.br/ handle/123456789/204693

Chagas, Miriam de F. (2005) Estudos Antropológicos nas comunidades remanescentes de quilombos: sinais que amplificam a luta por uma vida histórica, vida jurídica. Em: Leite, Ilka B. (org.). Laudos Periciais Antropológicos em debate. NUER, ABA. pp. $71-79$.

Chamorro, Graciela. (2008). Terra Madura, Yvy Araguyje: fundamentos da palavra guarani. Editora UFGD.

Chamorro, Graciela; Martins, Andérbio Márcio Silva. (2015). Diversidade linguística no Mato Grosso do Sul. Em: Chamorro, Graciela; Combès, Isabe1le. (Org.). Povos indígenas em Mato Grosso do Sul: história, cultura e transformações sociais. Ed. UFGD, 729 - 744.

Claval, Paul. (2002). A volta do cultural na Geografia. Revista de Geografia da UFC, ano 01, n. 01.

Contreras, Jesús. (1992). Alimentación y cultura: reflexiones desde la Antropología. Revista Chilena de Antropologia. n.11, 95-111.

Conversa com Povo Laklãnõ sobre Território Tradicional. (2020, 27 de outubro).
Página Opinião Pública Do Povo Laklãnõ/Xokleng. https:// www.facebook.com/Xokleng/ videos/2852111005023352

Crendô, Jair Ghoguin. (2015). O Espaço tradicional Xokleng/ Laklãnõ. (Tese de Licenciatura Intercultural Indígena do Sul da Mata Atlântica, Centro de Filosofia e Ciências Humanas, Departamento de História, Universidade Federal de Santa Catarina).

Criri, João. (2015). A Alimentação tradicional Laklãnõ (Xokleng). (Tese de Licenciatura Intercultural Indígena do Sul da Mata Atlântica, Centro de Filosofia e Ciências Humanas, Departamento de História, Universidade Federal de Santa Catarina).

Criri Neto, Aristides Faustino. (2015). Alfabetização na Lingua Laklãnõ/Xokleng na Escola Indígena de Educação Básica Laklãnõ. (Tese de Licenciatura Intercultural Indígena do Sul da Mata Atlântica, Centro de Filosofia e Ciências Humanas, Departamento de História, Universidade Federal de Santa Catarina).

Criri, Voia. (2020). Impactos da colonização e da barragem norte sobre a espiritualidade do povo Laklãnõ/Xokleng: memórias do ritual do Pétogdé. (Tese de Licenciatura Intercultural Indígena do Sul da Mata Atlântica, Centro de Filosofia e Ciências 
Humanas, Departamento de História, Universidade Federal de Santa Catarina).

Cuzugni, Vilma Couvi Patte. (2020). Dança das árvores e a dança da voz: jeito de dar nome as crianças no Povo Xokleng / Laklãnõ. (Tese de Licenciatura Intercultural Indígena do Sul da Mata Atlântica, Centro de Filosofia e Ciências Humanas, Departamento de História, Universidade Federal de Santa Catarina).

Dagnoni, Catia. (2018). O “outro” lado da Barragem Norte: território, memória e/m resistência. (Tese de Doutorado em Desenvolvimento Regional - Programa de Pós-Graduação em Desenvolvimento Regional, Universidade Regional de Blumenau).

Echeverrí, J. A. (2004). Territorio como cuerpo y territorio como naturaleza: diálogo intercultural? Em: Surrallés, A. e García Hierro, P. (Orgs.). Tierra adentro: territorio indígena $y$ percepción del entorno. Grupo Internacional de Trabajo sobre Asuntos Indígenas.

Escobar, Arturo. (2015). Territorios de diferencia: la ontología política de los "derechos al territorio". Cuadernos de Antropología Social, n.41, 25-37.

Flávio, Luiz Carlos (2011). Memória(s) e território: elementos para o entendimento da constituição de
Francisco Beltrão-PR. (Tese de Doutorado em Geografia - Programa de Pós-Graduação em Geografia, Unesp).

Gakran, Namblá. (2015). Elementos fundamentais da gramática Laklãnõ. (Tese de Doutorado em Linguística - Universidade de Brasília).

Geertz, Clifford. (1989). A interpretação das culturas. LTC.

Gonçalves, José Reginaldo Santos. (2007). Antropologia dos objetos: coleções, museus e patrimônios. Ministério da Cultura Instituto do Patrimônio Histórico e Artístico Nacional Departamento de Museus e Centros Culturais.

Haesbaert, Rogério. (2004). O mito da desterritorialização: do "fim dos territórios" à multiterritorialidade. Bertrand Brasil.

Haesbaert, Rogério. (2021). Território e descolonialidade: sobre o giro (multi) territorial/de(s)colonial na América Latina. CLACSO; Programa de Pós-Graduação em Geografía; Universidade Federal Fluminense. http://biblioteca.clacso.edu.ar/clacso/ se/20210219014514/Territorio-decolonialidade.pdf

Halbwachs, Maurice. (1990). A memória coletiva. Tradução de Laurent Leon Schaffter. Vertice.

Kluge, Anderson Rodrigo. (2020). Minhas crenças, minha religião. 
(Tese de Licenciatura Intercultural Indígena do Sul da Mata Atlântica, Centro de Filosofia e Ciências Humanas, Departamento de História, Universidade Federal de Santa Catarina).

Little, Paul E. (1994). Espaço, memória e migração: por uma teoria da reterritorialização. Textos de História, v. 2, no 4.

Little, Paul E. (2002). Territórios Sociais e Povos Tradicionais no Brasil: Por uma antropologia da territorialidade. Série Antropo$\operatorname{logia} \mathrm{n}^{\circ} 322, \mathrm{UnB}$.

Maldonado, L. (2014). El Sumak Kawsat/Buen Vivir/Vivir Bien: la experiencia de la República del Ecuador. Em: Hidalgo-Capitán, A. L.; García, A. G.; Guazha, N. D. (ed.). Sumak Kaesay Yuyay: antología del pensamiento indigenista ecuatoriano sobre Sumak Kawsay. Huelva y Cuenca: FIUCUHU, 193-210

Markus, Cledes; Oliveira, Lilian Blanck de. (2005). Ensino Religioso: memória e perspectivas. Em: Junqueira, Sérgio Rogério Azevedo; Oliveira, Lilian Blanck de. (orgs). Champagnat.

Meliá, Bartomeu. (1979). Educação indígena e alfabetização. Loyola.

Memórias Laklãnõ/Xokleng: Saberes e Resistências da e na Aldeia Bugio (Documentário) (2018). Em: EIEB VANHECU PATTÉ. Dossiê Experiências Pedagógicas de
Professores e Professoras Indígenas na E.I.E.B.

Munduruku, Daniel. (2017). Mundurukando 2: sobre vivências, piolhos e afeto - Roda de conversa com educadores. UK'A Editorial.

Munduruku, Daniel. (2020, outubro). Escrita indígena: registro, oralidade e literatura. Revista Emília http://revistaemilia.com.br/escrita-indigena-registro-oralidade-e-literatura

Neto, Jaime Bernardo. (2021). Sobre memória, identidade e territorialidade - reflexões a partir da Geografia. Geog Ens Pesq, v. 25 / 02, 1-26.

Oliveira, E. (2007). Filosofia da ancestralidade: corpo e mito na filosofia da educação brasileira. Editora Gráfica Popular.

Oyěwùmí, Oyèrónkẹ. (2002). Visualizing the Body: Western Theories and African Subjects. In: Coetzee, Peter H.; Roux, Abraham P.J. (eds). The African Philosophy Reader. Routledge, 391-415.

Oyěwùmí, Oyèrónkẹ́. (2017). La invención de las mujeres. Una perspectiva africana sobre los discursos occidentales del género. En la frontera.

Padilha, Margarete Vaicome Patte. (2020). Modos de transmissão, ensino e aprendizagem da língua Xokleng/Laklãnõ no contexto familiar e no ambiente escolar. 
(Tese de Licenciatura Intercultural Indígena do Sul da Mata Atlântica, Centro de Filosofia e Ciências Humanas, Departamento de História, Universidade Federal de Santa Catarina).

Paté, Abraão Kovi. (2014). Ensino da língua materna Xokleng/ Laklãnõ: $\quad$ silenciamento, opressão e resistência. Em: Keim, Ernesto Jacob. Org. Educação na diversidade étnica: educação escolar indígena no contexto pós e anticolonial. CRV.

Patté, Allair Ngaumm. (2015). Histórias cotidianas Laklãnõ. (Tese de Licenciatura Intercultural Indígena do Sul da Mata Atlântica, Centro de Filosofia e Ciências Humanas, Departamento de História, Universidade Federal de Santa Catarina).

Paté, Osias Tucugm. (2015). Mulheres Laklãnõ: Um estudo sobre gênero, geração e agência. (Tese de Licenciatura Intercultural Indígena do Sul da Mata Atlântica, Centro de Filosofia e Ciências Humanas, Departamento de História, Universidade Federal de Santa Catarina).

Patté, Ana Roberta Uglõ. (2015). Barragem Norte na Terra Indigena Laklãnõ. (Tese de Licenciatura Intercultural Indígena do Sul da Mata Atlântica, Centro de Filosofia e Ciências Humanas, Departamento de História,
Universidade Federal de Santa Catarina).

Pereira, Walmir da S. et al. (1998). Laudo Antropológico de identificação e delimitação de terra de ocupação tradicional xokleng: história de contato, dinâmica social e mobilidade indígena no sul do Brasil. FUNAI.

Popó, Carli Caxias. (2015). Cosmologia na visão Xokleng. (Tese de Licenciatura Intercultural Indígena do Sul da Mata Atlântica, Centro de Filosofia e Ciências Humanas, Departamento de História, Universidade Federal de Santa Catarina).

Povo Deni y Sass, Walter. (2014). A espiritualidade Deni. Em: Markus, Cledes; Altmann, Lori; Gierus, Renate. Saberes e Espiritualidades Indigenas. Oikos, p.29-52.

Pripra, Acir Caile. (2020). Ouvir os velhos, aprender com eles: memórias, histórias e conhecimentos dos anciões da Terra Indígena Xokleng/Laklanõ. (Tese de Licenciatura Intercultural Indígena do Sul da Mata Atlântica, Centro de Filosofia e Ciências Humanas, Departamento de História, Universidade Federal de Santa Catarina).

Pripra, Walderes Cocta. (2021). Lugares de Acampamento e Memória do Povo Laklãnõ/Xokleng, Santa Catarina. (Tese de Mestrado em História - Programa de Pós-graduação em História, 
Universidade Federal de Santa Catarina).

Pryzan, Raquel. (2020). A Fogueira Sagrada para os Índios Fulni-Ô. https://solanomundo.com. br/a-fogueira-em-yaathe

Raffestin, Claude. (1986). Por uma Geografia do Poder. Ática.

Raffestin, Claude. (2009). A produção das estruturas territoriais e sua representação. Em: Saquet, Marcos Aurelio; Sposito, Eliseu Savério (orgs.). Territórios e territorialidades: teorias, processos e conflitos. Expressão Popular, p.17-35.

Ramos, Alcida. (1986). Sociedades indígenas. Ática.

Sachs, J. (2000). Communication development in infancy. In: Gleason, J.B. The development of language. Ally and Bacon.

Santos, Boaventura de Sousa. (2004). Conhecimento prudente para uma vida decente: um discurso sobre as ciências revisitado. Cortez.

Santos, Sílvio Coelho dos. (1997). Índios e brancos no sul do Brasil: a dramática experiência Xokleng. Edeme.

Silva, Adnilson de Almeida. (2010). Territorialidades e Identidade do Coletivo Kawahib da Terra Indigena Uru-Eu-Wau-Wau em Rondônia: "Orevaki Are" (Reencontro) dos "Marcadores Territoriais. (Tese de Doutorado em Georgrafia - Programa de Pós-graduação em Geografia, Universidade Federal do Paraná).

Silva, Adnilson de Almeida. (2013, janeiro). Espiritualidade, territorialidade: interfaces das representações culturais coletivas indígenas. Raega - $O E S$ paço Geográfico em Análise, [S.1.], v. 27.

Tschucambang, Copacãm. (2015). Artefatos arqueológicos no território Laklãnõ/Xokleng (Tese de Licenciatura Intercultural Indígena do Sul da Mata Atlântica, Centro de Filosofia e Ciências Humanas, Departamento de História, Universidade Federal de Santa Catarina).

Tschucambang, Josiane de Lima. (2020). Ouvir os velhos, aprender com eles: memórias, histórias e conhecimentos dos anciões da Terra Indígena Xokleng/Laklanõ. (Tese de Licenciatura Intercultural Indígena do Sul da Mata Atlântica, Centro de Filosofia e Ciências Humanas, Departamento de História, Universidade Federal de Santa Catarina).

Tschucambang, Copacãm; Tschucambang, Josiane de Lima (2018). O Povo Laklãnõ-Xokleng. Em: Darella, Maria Dorothea Post et al (Orgs). $\tilde{A g}$ tõ LaklãnõXokleng ãg jákle vãnhló zi kũ: ãg jóba mé óg jávãn kũ tõ óg ze jógpalag jã. Consciência 
Laklãnõ-Xokleng em ação: jeitos de ensinar e aprender na terra indigena Laklãnõ. s.n, 21-26.

Tuan, Yi-Fu. (1983). Espaço e lugar. A perspectiva da experiência. Tradução de Lívia de Oliveira. Difel.

Weir, J. A. Quintero. (2019). Fazer comunidade: notas sobre território e territorialidade a partir do sentipensar indígena na bacia do Lago de Maracaibo. Deriva.

Weitschá, Micael Vaipon. (2015). Da história oral Laklãnõ/Xokleng para história em quadrinhos. (Tese de Licenciatura Intercultural Indígena do Sul da Mata Atlântica, Centro de Filosofia e Ciências Humanas, Departamento de História, Universidade Federal de Santa Catarina).

Westhelle, Vítor. (1990). Os sinais dos lugares; as dimensões esquecidas (preleção inaugural). Em: Dreher, Martin Norberto (org.). ed. Peregrinação; estudos em homenagem a Joachim Herbert Fischer pela passagem de seu $60^{\circ}$ aniversário. Sinodal, 255-268.

Xumayá Xya. (2020). Conversa com Povo Laklãnõ sobre Território Tradicional. Página Opinião Pública do Povo Laklãnõ/Xokleng. Facebook, 27 de outubro. https:// www.facebook.com/Xokleng/ videos/2852111005023352 
